\title{
Cedar, Tea and Stories: \\ Two Indigenous Women Scholars Talk About Indigenizing the Academy
}

\author{
Elizabeth Brulé \\ Queen's University \\ e.brule@queensu.ca \\ Ruth Koleszar-Green \\ York University \\ ruthkg@yorku.ca
}

\begin{abstract}
In an effort to redress the educational needs of Indigenous peoples as part of the Truth and Reconciliation Commission of Canada's call to action (2015), two Indigenous colleagues, Elizabeth Brulé and Ruth Koleszar-Green, came together to engage in a collective reflection on what Indigenizing the curriculum has meant to each of them. Through a collective dialogue that affirms that knowledge is created through our individual and collective storytelling, they discussed the challenges and successes that Indigenous women have encountered in their attempts to indigenize the curriculum over the past decade in the province of Ontario, Canada. Collaborative work such as this has not only provided them with an enriching intellectual and collective experience but has also given them cause for hope in their pursuit for truth and reconciliation. Through this collective dialogue, issues of Indigeneity, pedagogy, reconciliation and sisterhood are discussed.
\end{abstract}

Keywords: Indigenizing the academy, Indigenous pedagogy, post-secondary education, truth and reconciliation

Liz: In 2015, the Truth and Reconciliation Commission of Canada (2015) called upon post-secondary institutions to play a major role in redressing the educational needs of Indigenous peoples. Universities across Canada responded, instituting culturally appropriate programs and policy initiatives including mandatory courses for all students, language classes, and Indigenous strategic plans. While many of these initiatives are exemplary, involving the extensive participation of Indigenous communities, there is no consensus as to what indigenization means or how it is to be achieved within post-secondary institutions. In the fall and winter of 2017 and 2018, Ruth and I came together to discuss our experiences with Indigenizing the curriculum in the post-secondary sector and to share our understandings of what these efforts have meant to ourselves, our communities and to our students.

We met at Skennen'kó:wa Gamig (House of Peace)—our newly renovated space for Indigenous students, faculty and staff. Our purpose was to share our stories of the challenges and successes that we as Indigenous women have encountered in our attempts to Indigenize the curriculum in our respective fields. Collaborative work such as this has not only provided us with an enriching intellectual and collective experience but has also given us cause for hope in our pursuit for truth and reconciliation. What follows is a discussion of our collective stories and the Cultural and Pedagogical Inquiry, Fall 2018, 10(2), pp. 109-118

ISSN 1916-3460 () 2018 University of Alberta http://ejournals.library.ualberta.ca/index.php/cpi/index 
importance of Indigeneity, pedagogy, reconciliation and sisterhood in our journey for truth and reconciliation.

\section{Who Are We?}

Ruth: Oh, I love this space... there is something healing about sitting in the 'living room' of Skennen'ko:wa Gamig. The house is an old log cabin, nestled in a secluded woodlot on the campus of one of the largest universities in Canada. This beautiful cabin was renamed and officially opened on June 21, 2017, in a ceremony, attended by individuals across the campuses from students, staff, faculty, deans and even the president elect. The cabin is both a symbol of Indigenization and a start to decolonization. I am sitting down to a cup of tea, a bowl of soup and a fresh baked scone. I know that this meal will do more than feed my body, it will feed my soul and it will be an act of resistance and healing. I am sitting down with a brilliant and amazing Indigenous colleague who is more like an auntie or older sister. I know that soon my cheeks will hurt from laughing and my make-up might be smudged from crying. I also know that both my laughter and my tears are welcomed in this space.

Before we go any further, let us introduce ourselves as we have been taught (Kovach, 2009; Absolon, 2011; Baskin, 2016). My name is Ruth and I am Kanien'kehá:ka (Mohawk) from the Haudenosaunee Confederacy. I also have Celtic heritage on my father's side. I am Turtle clan. My most important work is being an Ista (mother) to two children here and one baby that returned to the Sky world. My identity is integral to the work that I do as an assistant professor in the school of social work. I am currently also the institutional co-chair for the Indigenous Council. I started my time at here in July of 2014 on a two-year contract, however before the completion of the first year, I moved into a tenure track position. My contribution to this conversation is based on my thesis research and as a social work professor.

Liz: Hi, my name is Elizabeth, but I go by Liz and I hail from the Ottawa/Gatineau area-which is on the traditional territory of the Algonquin and Métis Nations. While I was raised primarily in a traditional working-class Franco-Ontarian family with my paternal grandparents as my guardians, I am also of Métis heritage of the Mattawa/Ottawa Region Métis. While this complex and often denied heritage has often confounded my own understanding of my cultural and ancestral heritage, it has also added to my deep connection to the land and a more comprehensive understanding of what counts as knowledge outside the confines of a Eurocentric understanding of education. As a faculty member, in the Department of Equity Studies, at York University for the past ten years, bringing Indigenous knowledges into the classroom has been both an exciting and challenging endeavor-one that merits a serious examination of our roles and aims as Indigenous scholars, teachers and learners. I am mother to three incredible young adults and am excited to be sharing our stories and reflecting on our experiences. I hope to bring these reflections and knowledges to my new role as assistant professor in the Department of Gender Studies at Queen's University this fall 2018.

\section{What does Indigenization mean to you?}

Ruth: There are many ways and attempts being made to bring forth Indigenous knowledges in universities and educational spaces. As the number of Indigenous academics grows there will be more and more educational opportunities for Indigenous and non-Indigenous learners to develop a critical depth of knowledge on Indigenous topics, histories, worldviews and ideologies. In this article, we are intentionally using the word 'Indigenization' as there are two 
words that seem to be floating around academic spaces right now (and I am not talking about 'truth' and 'reconciliation'): they are 'Indigenization' and 'Decolonization'. Indigenization of education is the inclusion of Indigenous thought, theory, teachings, people and pedagogy into spaces of learning. Indigenization, while it can be personally profound, does not challenge and change the structures of dominance. As I have understood from Tuck and Yang (2013), decolonization is not some inclusion of Indigenous people and all is well and done. Decolonization is based on land and the rematriation of land.

There is, no doubt, a lack of knowledge in most Canadian educational institutions of the history of Indigenous and settler relations. This information is important. However, the history and the current implications of colonial discourse will not erase or eradicate Indigenous people's struggles alone. Teaching of culture in post-secondary programs may serve as an interest to some, but like a world religion course, cultural-based courses do not address the systemic oppression, nor do they provide a space for advancement of Indigenous practices and healing. As courses are designed, there is a need to discuss the Indian Act, the Residential school system and the Indigenous Child removal system (Sinclair, 2016), among many other topics. Approaches and theoretical foundations that centre Indigenous worldviews based on concepts of holistic relationships, experiential learning and critical self-reflexivity of the students' position and privilege are essential in our pursuits to Indigenize the curriculum. There is also a need however, to centre Indigenous knowledges as a way to disrupt the notion that Indigenous people have somehow 'lost' their culture. We have not lost a single thing. For many Indigenous people and communities, we did not put down our knowledges nor misplace them. Language, cultural protocols and practices, and other markers have been intentionally and violently removed. Indigenous peoples both in academia and out are striving to reclaim and rematriate. To say that we 'lost' anything projects, again, the violence of colonization upon us.

The Indigenization projects that are occurring across the country have a lot to do with the release and response to the Truth and Reconciliation Commission of Canada on the Indian Residential School System. For roughly 120 years, Indigenous children were taken away from their families and forced into 'educational' spaces that were designed to "kill the Indian in the child". In the 20 years since the last Residential school closed, there has been a lifted shroud of silence about the violence perpetuated in these schools. In the "Calls to Action", a document that was released in June of 2015, 96 interrelated calls were issued to redress the systemic and structural oppression that were pinnacle to the ideologies that perpetuated the Indian Residential School System (Truth and Reconciliation, 2015). The calls are, in some peoples' minds a checklist on how to ensure that Indigenous/Canadian relations are 'reconciled'. It is of my/our opinion that the calls are a starting point to hear and discuss a deeper level of truth. In my own mind, I usually change the words 'truth and reconciliation' to 'truth and information' as I believe before there can be new relationships between Indigenous and non-Indigenous people, there needs to be a lot more information shared.

Liz: I agree Ruth. A lot more information needs to be shared. We also need to share and acknowledge the work that Indigenous scholars have undertaken to Indigenize the academy and their historical struggles in doing so. As our amazing Mi'kmaq colleague, Bonita Lawrence, has shared with us, questions about the role of Indigenous knowledges were first raised in the academy in 1974, when Trent University first began teaching Native studies; however, it was not until 1986, when the Saskatchewan Indian Federated College (now First Nations University) began a strong policy of integrating Elders into their program that conflicting perspectives 
became evident, particularly as graduate degrees in Indigenous studies were created in different universities (B. Lawrence, personal communication, February 12, 2018). As she explains, at that point issues were raised as to how Elders' knowledge would be credited for supervision - which centrally involved questions about the value of Indigenous knowledges in an academy where western accreditation was not only the norm but was viewed as sacrosanct (B. Lawrence, personal communication, February 12, 2018). These questions have always been settled by administrators in an ad-hoc and one-sided manner, where universities' policies were created about how Elders' knowledge could be considered equal to academic knowledge (B. Lawrence, personal communication, February 12, 2018). Meanwhile, Indigenous faculty members and local Indigenous communities have called for more control over the process. Since the Final Report of the Truth and Reconciliation Commission (2015) was released, there have been widespread actions in universities across Canada to Indigenize the university. And yet, there is no consensus as to what this means and how 'it' is to be achieved. The debates that Indigenization is raising, the struggles of Indigenous faculty and communities around this, and the novel approaches that are being used are important to how Indigenous knowledges can be brought into the academy.

A definition of Indigenization that I think resonates well with various Indigenous worldviews is the University of Regina's recent definition. They define Indigenization as:

The transformation of the existing academy by including Indigenous knowledges, voices, critiques, scholars, students and materials as well as the establishment of physical and epistemic spaces that facilitate the ethical stewardship of a plurality of Indigenous knowledges and practices so thoroughly as to constitute an essential element of the university. It is not limited to Indigenous people, but encompasses all students and faculty, for the benefit of our academic integrity and our social viability (University of Regina, 2015, p. 1).

This particular definition places emphasis on "epistemic spaces" and a "plurality of Indigenous knowledges and practices" as being essential aspects of the university (University of Regina, 2015 , p. 1). Yet much of the scholarly literature over the past decade reveals that Indigenous knowledge and practices have not become essential elements of the university collegium (Kuokkanen, 2007; Armstrong, 2013; Darlaston-Jones et al., 2014; Simpson, 2014; Archibald et al., 2016; Koleszar-Green, 2016). That is not to say that efforts to do so have not been made. We can see in our own university the huge strides made to bring Indigenous scholars, students and knowledge into the collegium. That said, calls to indigenize the curriculum have often resulted in the overlaying of Indigenous content into the existing colonial framework of the academy, the result of which is the presentation of the history of the colonization of Indigenous people from a deficit perspective; that is, a perspective that highlights the negative social, cultural and economic problems that have emerged as a result of colonization without addressing the incredible strength and resilience of Indigenous people in our efforts to resist cultural genocide (Darlaston-Jones et al., 2014). We need to displace this colonial framework with our own varied Indigenous knowledges and practices — rather than overlaying, we must insist on introducing the epistemological and ontological understandings of our worldviews into the academy.

\section{What does reconciliation mean to you and what should it look like?}

Liz: I think there is a real misconception of the kind of role and responsibility that nonIndigenous people can play in the process of reconciliation and Indigenization. There is a tendency to believe that it is the Indigenous communities' responsibility to lead the way to Cultural and Pedagogical Inquiry, Fall 2018, 10(2), pp. 109-118

ISSN 1916-3460 @ 2018 University of Alberta http://ejournals.library.ualberta.ca/index.php/cpi/index 
reconciling with settlers. Whether such a belief is due to fear of doing the wrong thing, making mistakes or just feeling immobilized by a lack of knowledge, it is up to non-Indigenous peoples to acknowledge that colonialism is an ongoing reality and to take responsibility for the role they can play on the journey to reconciliation. Through understanding the historical and ongoing legacy of colonization, allies will be better able to engage with Indigenous communities in their efforts to seek justice. This said, I agree with you Ruth, the process of decolonization requires more than history classes. Allies need to make a commitment to honoring and sharing the land with Indigenous people through the rematriation of the land.

I believe that reconciliation also requires that we build relationships. These relationships need to be fostered by those at the top; that is, people in positions of power must be willing to take the time to build relationships with Indigenous communities, provide support, financial or otherwise, and be willing to let Indigenous people lead the way in how to move forward. I think one of the best examples of this kind of relationship building is the REDress Project that took place at York University this past Winter term, 2018. Student leader, Kanisha Brown-Bear, from the Indigenous Students Association at Glendon (ISAG), and myself, in cooperation with the Indigenous Council at York (ICY), the Aboriginal Students Association at York (ASAY) and allies from both campuses, came together to install over 150 red dresses to commemorate and honor the over 1500 missing and murdered Indigenous women, girls, transgender and two-spirit persons. A working group made up of 12 people from various departments met over a six-month period to ensure the success of the project. With Indigenous students and faculty as the leads, the York community provided extensive expertise, funding, administrative and presidential support. From maintenance, to security personnel, to communications and accounting staff, folks gave their time and weekend to help collect, prepare and hang red dresses across the Keele and Glendon campuses. Over 50 student allies helped to install the dresses and facilitate the two REDress plenary events that featured guest speaker, Glendon's Anishinaabe linguist, Maya Chacaby and, Winnipeg-based Métis artist, Jamie Black. Everyone that participated and supported the REDress Project did so with love, respect, reciprocity and friendship which I think attributed to its amazing success.

Ruth: I agree with you Liz; the REDress Project was an excellent experience and example of Indigenous and non-Indigenous people working together to bring forward truth and information. I do not think I will ever forget that moment in the Commons when you pointed to the President's office window, seeing a REDress hanging in that space! WOW!

I think that there are many ways that non-Indigenous folks can step up and move forward to support Indigenous people as we do the work we are hired to do. I also want to acknowledge that I have had much support and mentorship from many Indigenous scholars across the country as well as from strong allies in my school, faculty and across the university. Mentorship from non-Indigenous people willing to do their work are foundational to any advancement of Indigenization. It is impossible for Indigenous people to take all of the responsibilities. NonIndigenous people have a huge role to play; however, these roles are not the same.

I have been fortunate to have the guidance and access to senior scholars, both Indigenous and non-Indigenous who are committed to building a more hospitable space for Indigenous scholars. I have really been supported to challenge and ask questions about the system and structures. I have been encouraged to be true to my authentic self. I have been supported as a scholar with a strong theoretical foundation that is distinct from dominant western ideologies. 
When I joined my faculty, many non-Indigenous allies had been working to create a space that would be hospitable to Indigenous knowledges and scholarship. I remember my job interview when the then director used the analogy of Indigenization of social work as a train system. She said something like "we are still in the station" to which I replied, "that is okay, because I have a bunch of tickets that can take you different places!" (B. Heron, personal communication, April 23, 2014).

In a recent conversation with the same colleague, I was asking how she was adjusting after her sabbatical and the 6 previous years as director of the school. She told me that it was "nice just to be a fish swimming in the pond". I laughed and said that I could not wait for that time because as a pre-tenure fish, I feel like I am always swimming upstream. Her response really impacted me. She told me that I should not settle for this pond and that she saw me destined for a much bigger pond (B. Heron, personal communication, October 14, 2017).

Her words and metaphors really sum up my experience so far at York. A train still in the station with so many possible destinations and adventures ahead! I, the provider of tickets/ knowledge? A little fish trying to swim upstream being told, that the pond they think will be their home is already too small. Indigenization is not an easy road, it might not even be a road. But I am hopeful that in the end, the train will drive by a beautiful large pond that reflects back all the mileage and adventures that the train has travelled.

\section{What have been some of the challenges and successes you have experienced in your attempts to introduce and use Indigenous pedagogies in your class? What more can be done to incorporate Indigenous worldviews into the academy?}

Ruth: I love teaching! I love storytelling even more. I love building relationships with the individuals in the classroom. I love learning from all the knowledge that is in the class. As an Indigenous educator, I do not see my teaching as a banking model of learning (Freire, 1970), but as a way to communicate and share experiences.

I am a strong believer that Indigenous pedagogies (the way we teach) are just as important as what we teach. My doctoral work (Koleszar-Green, 2016) discussed with nonIndigenous learners their understandings and experiences in an Indigenous topic course, taught by an Indigenous person who utilized Indigenous teaching pedagogies. In disrupting the colonial knowledge systems by teaching Indigenous history, theory, practice or knowledges, in a way that is in line with Indigenous teaching methods (experiential learning, storytelling, relationship building, etc.), non-Indigenous students demonstrated a deeper commitment and understanding of responsibilities to Indigenous solidarity.

I remember when I was a PhD student, taking a course on Indigenous worldviews and implications to education, I challenged my brilliant Indigenous professor on the fact that he needed to spend weeks discussing the history of colonization even before we could start a discussion about "the good stuff", Indigenous worldviews. I remember that he told me something like "I cannot leave all of the other students behind to teach to only a few of you". I did not like this answer at the time because I wanted to have a higher-level discussion. I felt entitled to learning that is relevant to advancing my own understandings and then I was reminded of a teaching. In learning from Knowledge Keepers, I have been told that when I hear a teaching over and over again, I will take something different from it each time. I now find myself echoing the wise words of my amazing Indigenous professor. 
"I acknowledge that there is overlap between this course, as it is currently designed, and the Bachelor of Social Work course. This is due to the lack of background knowledge that students have on this topic. In the coming years, this course will be restructured to have more of a focus on research and theory at a graduate level." (Course proposal, Koleszar-Green, 2016)

This was the disclaimer that I included on a new Master of Social Work (MSW) course that I designed for a mandatory course on Indigenous social work and worldviews for the school that I teach at. As a school, we have implemented a mandatory course at the undergraduate level (taken in second year of a four years honours program) and at the MSW level. I realize that many of my future students would not be able to have the discussions about critical social work practice, and approaches with regard to Indigenous people and theory, due to the lack of exposure that the majority of students have had throughout their education.

As the majority of my students are non-Indigenous, I constantly need to find ways to balance between the few Indigenous students in the room and the lack of knowledge that is evident through the colonial education. One of the ways that I have been able to do this is to support Indigenous students (if they so choose) to share their knowledge while trying to find ways to inspire and advance their learning. I will admit, that this might be "extra" work for me, but it also means that their papers, presentations, and office hour visits become a space where we discuss Indigenous theory and practice at a level that advances both my own and their knowledge. ${ }^{\mathrm{i}}$

In our cedar and tea discussions, you and I have spoken about how hard it is to teach mixed classrooms. I really think that Indigenous pedagogies are supportive of advancing Indigenous students' knowledge while at the same time bringing non-Indigenous people to a level of conversation and learning that challenges them. If I was to teach from a more 'conventional' lens or framework, I am not sure that I would be able to bridge the lived knowledge of Indigenous students and the lack of visibility that non-Indigenous students might enter the classroom with.

In a talk that I have given, I laid out the roles and responsibilities of both Indigenous and non-Indigenous educators. The inclusion of the history of colonization taught by Indigenous people really does not advance decolonial thought. It is with the commitment of all educators to unveil power and privilege of settler colonies that can start to shift the relationship and responsibilities of educator's roles to Indigenous communities.

In my classrooms, I usually start conversations of colonization off with asking students to name mechanisms of colonial rule - for example, the Indian Act, land theft, Residential schools, and child welfare. I write them on the board, one over the next so that they obscure the word beneath. I then ask students if these were anything that Indigenous people created. I tell them that untangling this mess of ideologies is not my job. It is their responsibility.

Liz: When I think of Indigenous pedagogies I am reminded of Thomas King's (2003) quote, "The truth about stories, is that's all we are" (p. 3). Stories allow us to engage in critical reflection about who we are and where we have come from. I am also reminded of the Métis approach to knowledge. We learn from the earth, we learn from animals, we learn in our observations and participation with the environment. We are part of the environment, we are not apart from it. In this Indigenous pedagogy, there is no hierarchy. Children teach Elders and 
Elders teach children. We also learn from our family relationships. Cultural values are shared in our stories - family, community and everyday relationships - they are all interrelated.

This Métis worldview has shaped my classroom pedagogy. Like you Ruth, I use Indigenous pedagogies that involve experiential learning, storytelling and relationship building. I think an Indigenous pedagogy encourages students to think reflexively about the course content, the stories and teachings they encounter and their own lived experiences. I also think that through partnerships with Indigenous communities, students are able to engage with Indigenous Knowledge Keepers that provide teachings on the importance of language acquisition, one's relationship to the land, the role of ceremonial practices and community empowerment. It is no doubt a balancing act to provide both non-Indigenous students with important information about the devastating effects of colonization, while at the same time providing Indigenous students with opportunities to delve into their respective Indigenous teachings more deeply. But I think the extra effort to do this 'double think' is important if we are going to have a pedagogy that challenges colonial educational practices and theories, and have students question their role in relation to Indigenous communities.

In my first year Equity Studies course, Introduction to Indigenous Thought, I invited several guest speakers from Indigenous communities to visit and speak with our class. Glendon's Anishinaabe linguist, Maya Chacaby, was one of our guests who came to speak about the importance of preserving and reviving Indigenous languages. But rather than providing students with only the 'facts' or information about language dispossession and loss, she engaged the students in a circle activity that Elder Rod Jefferies had shared with her. She began her activity with a traditional story about cognitive imperialism and then took the group through an exercise that allowed them to experience what theft of culture and kin networks felt like. She also used a symbolic knowledge bundle to represent what sociologists refer to as cultural continuity and illustrated how language was a central feature to the maintenance of culture. From a western worldview, the 'loss' of ones' cultural identity is explained from this intellectual point of view. But through Maya's circle exercise, the students began to understand theft of one's identity, kin relations and cultural and spiritual practices from an Indigenous worldview. We cried, we laughed, and we shared what we had learned together that day. It was a powerful teaching-one that changed my life and many of my students' lives. It was a perfect moment of learning from the heart; that is, knowing through our emotions which is considered an equally important way of knowing within many Indigenous knowledges.

Ruth, you mentioned something that I think is really important and that is that the inclusion of the history of colonization does not, in itself, advance decolonial thought. I think this is so true. I have found that one way to help move our students towards decolonial thinking is to engage them in experiential learning opportunities with Indigenous organizations that are working to effect change. I am not referring to the idea that they simply attend an event, but rather that they become involved and give back to the community in a meaningful way. This year my students had a choice to participate in one of five Indigenous events/actions: The Métis Rendezvous, Walking with Our Sisters, The Great Lakes Water Walk, The Moose hide Campaign or The REDress Project. From my students' comments and reflections, I could see major shifts in both their understanding and perspective on the issues we had discussed throughout the course. For many, a shift in their worldview occurred and they began show a deeper appreciation for the need to take collective responsibility in the process of reconciliation. After participating in the REDress Project, one student stated that he realized that this calling 
was one that every settler in the room needed to take. He said, "we need to take responsibility for, and stand-up against, a broken and racist system that has resulted in thousands of murdered and missing Indigenous women, girls and two-spirited people" (Anonymous, personal communication, March 4, 2018). For some of the Indigenous students in the class, their participation also resulted in feelings of pride and the importance of sharing their Indigenous worldviews. One student shared this with me: "This course has allowed me to feel closer to my own Indigenous identity, and less apprehensive to share my experience with others and engage myself in my community" (Anonymous, personal communication, April 3, 2018). It is recognitions like these that make Indigenous pedagogies so important in our efforts to Indigenize the academy.

\section{What has collaborative work such as the sharing of our stories about Indigenizing the academy meant to you?}

Ruth: The sisterhood and friendship that I have found amongst my Indigenous colleagues is truly one of the most profound engagements I have in my professional life that spills right into my personal. The weekend that Liz discussed earlier, when we installed the REDress Project, I brought my children to 'help'. As I introduced them to Liz, they immediately called her "Auntie Liz". The reason that this is important to discuss is not that Liz is going to babysit for me or spoil my kids on their birthdays, but is directly related to our shared and respective Indigenous worldviews. For Indigenous academics, this is not just a theoretical articulation but also a core piece of who we are and the relationships we have with one another.

One of the last stories that I want to tell occurred this past year. My amazing Mi'kmaq colleague and I teach the same mandatory second year social work course. After teaching about the role of social workers and the child welfare system, we found ourselves sitting first in my office debriefing. We both agreed that we had "work to do" (the never-ending grading, emails and other responsibilities that go along with our jobs) so said good-bye. However, less than 20 minutes later, I found my way to her office where we sat mostly in silence doing our work in each other's presence. The topic we had just taught was hard. The sisterhood we sought out was about healing, just as writing this article with my kids' Auntie Liz has been.

Liz: Being Auntie Liz to your children Ruth is so important to me spiritually, relationally and familially. I love your analogy of how our friendship and care in the workplace spills over into our personal lives. The sisterhood and friendship that I have with my Indigenous colleagues has been central to my ability to flourish and grow intellectually and emotionally, and, most importantly, it has sustained me in the everyday work we do in our efforts toward decolonization and Indigenous liberation. The best part of this collaborative work is that it is based on reciprocity, relationship building and responsibility to each other, our families and our communities. When your work involves this kind of responsibility, you have no choice but to develop meaningful and deep relationships_-ones that will last generations to come.

\section{Endnote:}

${ }^{\text {i }}$ I have made the decision never to ask students to self-identify in a classroom. I always make the assumption that there are no Indigenous students in the room as a means of halting the labour that Indigenous (and other marginalized students at times) students are expected to provide. I also acknowledge that their assignments might not be identical as I support students engaging with knowledges from their specific Nation.

Cultural and Pedagogical Inquiry, Fall 2018, 10(2), pp. 109-118

ISSN 1916-3460 @ 2018 University of Alberta

http://ejournals.library.ualberta.ca/index.php/cpi/index 


\section{References}

Absolon, K. (2011). Kaandossiwin: How we come to know. Halifax: Fernwood.

Armstrong, H. (2013). Indigenizing the Curriculum: The Importance of Story. First Nations Perspectives, 5(1), 37-64.

Archibald Q'um Xiiem J., \& Hare J. (2016). Indigenizing Education in Canada. Forum on Sharing the Land, Sharing a Future: Realizing the Promise, Facing the Challenge of Reconciliation, Nov. 2-4.

Baskin, C. (2016). Strong helpers' teachings: The Value of Indigenous knowledges in the helping professions. Toronto: Canadian Scholar's Press Inc.

Darlaston-Jones, D., Herbert, J., Ryan, K., Darlaston-Jones, W., Harris, J., \& Dudgeon, P. (2014). Are we asking the right questions? Why we should have a decolonizing discourse based on conscientization rather than indigenizing the curriculum. Canadian Journal of Native Education, 37(1), 86-104.

King, T. (2003). The truth about stories: A Native narrative. Toronto: Anansi.

Koleszar-Green, R. (2016). Understanding your education: Onkwehonwe and Guests Responsibilities to Peace, Friendship and Mutual Respect. Unpublished PhD Thesis, University of Toronto.

Kovach, M. (2009). Indigenous methodologies: Characteristics, conversations and context. Toronto: University of Toronto Press.

Kuokkanen, R. J. (2007). Reshaping the University: Responsibility, Indigenous Epistemes and the Logic of the Gift. Vancouver: UBC Press.

Simpson, L. (2014). Land as pedagogy: Nishnaabeg intelligence and rebellious transformation. Decolonization: Indigeneity, Education and Society, 3(3), 1-25.

Sinclair, R. (2016). "The Indigenous Child Removal System in Canada: An examination of legal decision-making and racial bias". First Peoples Child \& Family Review, 11(2), 8-18.

Truth and Reconciliation Commission of Canada. (2015). The Final Report of the Truth and Reconciliation Commission Recommendations. Toronto: McGill-Queen's University Press.

Tuck, E. and Yang, K. W. (2013). Decolonization is not a Metaphor. Decolonization: Indigeneity, Education \& Society, 1(1), 1-40.

University of Regina (2015). Indigenous Advisory Circle. Regina: University of Regina. Retrieved from: https://www.uregina.ca/strategicplan/priorities/indigenization.html 